\title{
Level-oriented modular training within teaching monologic speech to junior students
}

\section{Treinamento modular orientado ao nível no ensino de fala monológica para alunos juniores}

\section{Entrenamiento modular orientado a niveles dentro de la enseñanza del habla monológica a estudiantes junior}

\author{
Margarita Victorovna Myltseva ${ }^{1}$ (D) Ekaterina Alexandrovna Drozdova ${ }^{1}$ (D) , \\ Marina Georgiyevna Sergeeva² (D) Dmitry Vladimirovich Lukashenko²
}

\footnotetext{
${ }^{1}$ Peoples' Friendship University of Russia (RUDN University), Moscow, Russia.

${ }^{2}$ Research Institute of the Federal Penitentiary Service of Russia, Moscow, Russia.
}

Corresponding author:

Margarita Victorovna Myltseva

Email: myltseva_mv@pfur.ru

How to cite: Myltseva, M. V., Drozdova, E. A., Sergeeva, M. G. \& Lukashenko, D. V. (2021). Level-oriented modular training within teaching monologic speech to junior students. Revista Tempos e Espaços em Educação, 14(33), e16095. http://dx.doi.org/10.20952/revtee.v14i33.16095

\begin{abstract}
The expansion of the spheres of political, trade, economic and cultural cooperation between Russia and other countries creates real preconditions for intercultural professional communication in all areas of language experts' activity: teaching, researching, translating, interpreting and speaking for the peers. In these conditions, learning to provide a monologue in different world languages is becoming increasingly important to future linguists. According to the requirements of the new Federal Standard for Higher Professional Education, a linguist must be able to perform intercultural communication in various professional fields, conduct business negotiations, be an active participant in conferences, workshops and roundtable discussions using several working languages and search for topical information to improve his/her professional skills in the field of intercultural communication. Thus, the standard reflects the strategy of modern foreign-language education aimed to form the cultural and linguistic personality of the language expert who has reached a high level of the foreign-language professional communicative competence, which manifests itself in speech culture, an open-minded attitude to unfamiliar traditions and ways of life, along with the abilities for monologue and international professional communication. High-quality monologic speech is a personally and professionally significant skill, due to which specialists do not have difficulties with business conversations, reports, public messages and presentations in Microsoft PowerPoint and freely participate in discussing the course and prospects of joint activities. Mastering such skills begins at the very beginning of learning a foreign language in a higher
\end{abstract}


educational institution to be able to work with complicated scientific texts and prepare creative monologues as a postgraduate student.

Keywords: Monologic Speech. Modular Training. Foreign-Language Education. Linguists. ForeignLanguage Communication.

\section{RESUMO}

A expansão das esferas de cooperação política, comercial, econômica e cultural entre a Rússia e outros países cria pré-condições reais para a comunicação profissional intercultural em todas as áreas de atividade dos especialistas em línguas: ensino, pesquisa, tradução, interpretação e fala para os pares. Nessas condições, aprender a fornecer um monólogo em diferentes línguas mundiais está se tornando cada vez mais importante para os futuros linguistas. De acordo com os requisitos da nova Norma Federal para Educação Profissional Superior, um lingüista deve ser capaz de realizar comunicação intercultural em vários campos profissionais, conduzir negociações comerciais, ser um participante ativo em conferências, workshops e mesas redondas em vários idiomas de trabalho e pesquisar por informação temática para melhorar as suas competências profissionais no domínio da comunicação intercultural. Assim, o padrão reflete a estratégia da educação moderna de línguas estrangeiras que visa formar a personalidade cultural e lingüística do especialista em línguas que atingiu um alto nível de competência comunicativa profissional em língua estrangeira, que se manifesta na cultura da fala, uma atitude voltada para tradições e modos de vida desconhecidos, juntamente com habilidades para monólogo e comunicação profissional internacional. A fala monológica de alta qualidade é uma habilidade significativa pessoal e profissionalmente, devido à qual os especialistas não têm dificuldades com conversas de negócios, relatórios, mensagens públicas e apresentações em Microsoft PowerPoint e participam livremente na discussão do curso e perspectivas de atividades conjuntas. O domínio de tais habilidades começa logo no início da aprendizagem de uma língua estrangeira em uma instituição de ensino superior para ser capaz de trabalhar com textos científicos complicados e preparar monólogos criativos como um estudante de pós-graduação.

Palavras-chave: Discurso monológico. Treinamento modular. Educação em Língua Estrangeira. Lingüistas. Comunicação em língua estrangeira.

\section{RESUMEN}

La expansión de las esferas de la cooperación política, comercial, económica y cultural entre Rusia y otros países crea condiciones previas reales para la comunicación profesional intercultural en todas las áreas de la actividad de los expertos en idiomas: enseñar, investigar, traducir, interpretar y hablar para los pares. En estas condiciones, aprender a proporcionar un monólogo en diferentes idiomas del mundo se está volviendo cada vez más importante para los futuros lingüistas. De acuerdo con los requisitos del nuevo Estándar Federal de Educación Profesional Superior, un lingüista debe ser capaz de realizar comunicación intercultural en diversos campos profesionales, realizar negociaciones comerciales, ser un participante activo en conferencias, talleres y mesas redondas utilizando varios idiomas de trabajo y buscar información de actualidad para mejorar sus competencias profesionales en el ámbito de la comunicación intercultural. Por lo tanto, el estándar refleja la estrategia de la educación moderna en lenguas extranjeras destinada a formar la personalidad cultural y lingüística del experto en lenguas que ha alcanzado un alto nivel de competencia comunicativa profesional en lenguas extranjeras, que se manifiesta en la cultura del habla, una cultura abierta. actitud mental hacia tradiciones y formas de vida desconocidas, junto con las habilidades para el monólogo y la comunicación profesional internacional. El habla monológica de alta calidad es una habilidad personal y profesionalmente significativa, debido a que los especialistas no tienen dificultades con las conversaciones comerciales, informes, mensajes públicos y presentaciones en Microsoft PowerPoint y participan libremente en la discusión del curso 
y las perspectivas de actividades conjuntas. El dominio de tales habilidades comienza desde el comienzo del aprendizaje de un idioma extranjero en una institución de educación superior para poder trabajar con textos científicos complicados y preparar monólogos creativos como estudiante de posgrado.

Palabras clave: Habla monológica. Entrenamiento modular. Educación en lenguas extranjeras. Lingüistas. Comunicación en lenguas extranjeras.

\section{INTRODUCTION}

Nowadays the process of teaching monologic speech (MS) is oriented towards intercultural professional foreign-language communication. Thus, linguists should have the foreign-language monologic competence, which allows fulfilling monologic communication within international interuniversity partnership. Therefore, the orientation towards the development of the foreignlanguage monologic competence is a strategic goal that requires the enrichment of the educational process with new forms and methods providing a truly communicative focus of teaching MS, along with students' high motivation and educational mobility in mastering the skills of intercultural monologic communication.

The study of the problem shows that the requirements for the students' level of training, established by the MS standard, are traditionally fulfilled via textbooks and teaching aids in a foreign language recommended for linguistic faculties. These resources cannot satisfy the students' needs in all areas of specialization. The active work with additional educational material - accessible, relevant, informative and reliable texts - could contribute to the effective MS skills development in modern students. However, we observed that teachers pay more attention to grammatical structures and lexical units than practical MS skills with due regard to its communicative functions.

A conversation with junior students revealed the difficulties that they experience when preparing a monologic statement. All these complications are due to psychological factors (low motivation, fear of making mistakes, lack of confidence in the correctness of expressing one's thoughts, etc.) and insufficient experience in working with various texts through all the stages of constructing a monologic statement.

It becomes obvious that MS should be developed using a certain methodological system, based on a scientifically grounded concept, which, in its turn, rests on a set of principles determining the structure and content of the learning process.

The present stage of methodological science development involves a solid scientific base for considering the theoretical and methodological foundations of teaching MS to future linguists via the modular method. The resolution of the international conference "Modular teaching in the field of teaching foreign languages" (2006) emphasizes the theoretical and practical significance of the modular method in preparing linguists for professional activity in the framework of international cooperation. The document notes that the modular training system is mobile and ensures the continuity of the levels of mastering the foreign-language communicative competence. According to discussion participants, the interrelation of the modules contributes to forming and developing the skills and abilities of dialogic and monologic communication within professional communicative environment and in the context of international scientific communication.

More and more students of linguistic specialities understand that solving professional problems requires mastering MS skills, which is proved by the results of interviewing junior students. Thus, out of 126 interviewed participants, 63\% expressed the opinion that the MS skills are crucial for linguists' professional and scientific activities; $23 \%$ of students believe that MS skills will allow them to become full-fledged participants of international scientific and practical events and mobility programmes; $14 \%$ of students classify MS skills as quite complex ones, since they are associated with selecting and analyzing information materials necessary for an oral report, reading scientific works, translating and abstracting. All participants expressed their readiness to develop 
MS skills for professional communication with representatives of different cultures, both through dialogue and monologue. The key arguments involved the prospects for participation in international interuniversity research projects and mobility programmes, sports and cultural events. Among the "adjourned" advantages (i.e. those relevant after the graduation), interprofessional communication was mentioned (Bírová et al., 2018; Dolzhich \& Dmitrichenkova, 2018).

Thus, students regard a linguist's proficiency in oral MS as an important practical skill.

Meanwhile, our observations and experimental research show that junior students do not show high results in MS as a type of creative speech activity. Although many future specialists who participated in the teaching experiment do not make multiple lexical and grammar mistakes, they cannot express their thoughts logically and reasonably to arouse the interlocutor's interest in the problem or situation, which indicates insufficiently developed skills of unprepared MS. Having observed the students' monologic statements prepared by them in advance, we discovered that their speech commonly comes to "commentless" retelling of the text on a particular problem. Only a few people presented a monologue as a creative speech activity associated with logical thinking, the critical assessment of the solution to a problem that they consider through the prism of their personal life experience.

\section{LITERATURE REVIEW}

In domestic higher education, teaching MS does not consider its characteristic features that psychologists indicate in their studies. A disadvantage in the future specialists' training is the absence of modern programmes for teaching MS which would correspond to the contemporary tasks of linguistic education at the stage of forming a new, intercultural paradigm of professional foreign-language education, orienting the process of teaching oral dialogic and monologic speech to intercultural learning and intercultural communication. This means that mastering a foreign language as a means of communication and a way of integration into the multilingual polycultural space of another society becomes a priority in teaching a foreign language. This process contributes to cultivating a humane attitude towards national and world values (historical and cultural), the way and style of other peoples' life, their mentality and traditions.

A paradigm, in its broad sense, is a set of theoretical and methodological provisions adopted at a certain stage in the development of science and used as a model and standard for scientific research, interpretation, assessment and systematization of scientific data, for understanding hypotheses and solving problems that arise in the process of acquiring scientific knowledge.

In methodological science the intercultural paradigm is traditionally understood as a system of theoretical and methodological provisions in the field of intercultural education aimed at creating a secondary linguistic personality - that of a citizen of the world who respects his/her mother tongue, culture and mentality, but demonstrates tolerant attitude towards foreign ones.

Over the past decades many works were published on the issues of oral speech. Most researchers focus on teaching methods that can be used to achieve the best results in language skills. According to the well-known Russian scientist I.V. Rakhmanov, the successful development of oral speech requires, first of all, such conditions as relevant topics, knowledge of the corresponding language material, understanding the situation and having an incentive to speak (Rakhmanov, 1966).

Undoubtedly, the stimulus to mastering oral speech in a foreign language will be the students' vision of the prospects of applying speech and language skills in natural life situations. Therefore, I. V. Rakhmanov believed that if a person is learning a foreign language to speak with foreigners who come to our country, then the teacher should give preference to topics about this state. This information will be interesting to foreign guests, and Russian students will have the opportunity to show their erudition sharing the knowledge of the sights, cultural monuments, life 
of young people and their educational institution. The scientist believes that teaching to read requires using texts which will inform the students about all aspects of the daily and cultural life of the target language country. Thus, I. V. Rakhmanov emphasized the expediency of differentiating topics for oral speech (conversation about Russian reality) and for reading (acquaintance with the country of the studied language). He regarded this as an important incentive to motivate students to master oral speech.

One of the forms of oral speech is MS, which attracts the attention of many researchers.

In methodological science MS is considered as a productive type of oral speech activity aimed at developing the skills of foreign-language monologic communication. Teaching oral speech in a foreign language is difficult and "labour-intensive" process (according to B. A. Lapidus) (1986). The complexity of teaching oral speech is due to the fact that expressing one's thoughts in a foreign language requires knowing a certain number of lexical units, grammatical forms and intonation patterns and using this language material in practice. Secondly, the students should be able to combine these elements of the language structure to express their thoughts, focusing on the semantic side of their speech.

Thus, before performing speech actions the students should master the information about a particular linguistic fact (for example, about the form and use of a word in a particular context), acquire the skills and abilities to apply these phenomena and then learn to formulate their thoughts using the studied linguistic facts. Therefore, mastering spoken language is a three-step process. At each stage of training it is important to repeat linguistic phenomena and speech patterns, train and consolidate the ability to express one's thoughts in a foreign language. According to the Doctor of Pedagogical Sciences, Professor B. V. Belyaev, speaking a language is a competence based on solid speech skills, the development of which requires much time and many efforts (Belyaev, 1965).

In the works of Russian linguists (Gorev et al., 2018; Vasbieva et al., 2018; Sharonova, Trubnikova \& Sokolova, 2018) MS is defined as a person's speech addressed to one or several listeners to convey information in a more or less detailed form, express one's thoughts, intentions, evaluate events and phenomena, influence listeners by persuading or encouraging them to act. Doctor of Pedagogical Sciences, Professor G. V. Rogova interprets the monologue as a form of oral coherent utterance, of presenting thoughts by one person. It consists of logically interrelated sentences pronounced with certain intonation and united by a single content or subject (Rogova \& Rozhkova, 2012).

Analyzing and summarizing the issues of teaching oral speech, Doctor of Pedagogical Sciences, Professor, the full-fledged member of the Russian Academy of Sciences A. A. Mirolyubov notes that the monologue is a rather detailed type of speech activity, which uses relatively little non-speech information obtained from the conversation (Mirolyubov, 2001).

In M. V. Kuimova's opinion, MS is an active and arbitrary type of speech, for which a speaker should have some topic and be able to use it as a base for an utterance or a sequence of utterances (Kuimova, 2005). Besides, it is an organized type of speech, which implies the ability to programme not only a single statement or sentence, but also the entire message as a whole. This requires using the language tools which are adequate to the communicative intention, along with certain nonlinguistic communicative means of expressing thoughts (primarily intonation). MS is inseparable from the speaker's communicative goals. Communicativeness is a fundamental factor that ensures the communication adequacy at the logical and semantic levels.

In the scientific works of domestic and foreign scientists who study the methodology and technology of modular training (Skinner, 1968; Kurch, 1995; Volkova \& Panchenko, 2018; Blinova, Dugina \& Zabolotskikh, 2018), the latter is a special didactic system, which is a combination of various forms and methods of joint activity of the teacher and the students. This system is organized in special units (modules) for more effective mastering of educational material and improving the general quality of teaching. 
In other words, the essence of modular training is that each student can follow his/her individual curriculum, which contains a target programme of actions, an information bank and a methodological guide for achieving the didactic goals. The goal of modular training is seen in developing students' intellectual potential, their ability to manage educational and cognitive activities without the teacher's assistance. Young people should learn to acquire new knowledge independently, expand their educational horizons and objectively evaluate their knowledge as a result of intellectual work.

Regarding the module as the key unit of a modular programme for teaching a foreign language, Yu. Kovaleva (Kovalyova, 2011) writes that the above-mentioned component can act as an independent training programme, individualized in terms of content, teaching methods, independence level and pace of the student's educational and cognitive activity, which is characterized by presenting information in blocks and is intended for students with different levels of the foreign-language communicative competence. The author emphasizes that it should include a target plan of the student, an information bank and a methodological guidance to the teacher on how to achieve the student's didactic goals. Substantiating the advantages of the modular technology, the researcher notes that modular training is successfully combined with the traditional training system, influencing the development of a qualitatively new level of teacher-student relationships.

Russian scientists (Vasbieva et al., 2018; Dolzhich \& Dmitrichenkova, 2018; Sysoyev \& Yevstigneyev, 2010) study the use of modular teaching of foreign languages, identifying and substantiating the characteristic features of teaching a foreign language through the modular approach. The main feature of modular training is that it provides systematic training, and they also justified a number of characteristic features of modular training, among which it is noted that all students can work independently, achieve a specific goal of educational and cognitive activity and consolidate knowledge on a specific topic.

It is common contemporary knowledge that independent activity develops the skills of selforganization, self-control and self-esteem. Modular training, the initial component of which is the module, helps to solve a number of training and educational problems, such as using students' personal experience, developing individual cognitive abilities, differentiating the learning process and establishing the teacher-student cooperation. The module may be regarded as a learning tool, since it includes a target action plan, an information bank and a methodological guide to achieving the didactic goals. Therefore, it can act as a training programme, individualized in terms of its content, teaching methods, an independence level and the pace of the student's educational and cognitive activity.

According to Russian scientists V. M. Garayev, S. I. Kulikov and E. M. Durko (Garayev, Kulikov \& Durko, 1987), the "module" is a generalized set of various types and forms of the educational process. In P. Yutsyavichene's scientific publications (Yutsyavichene, 1989) the module is presented as a complete, logically consistent information base, a programme of the educational process which is a methodological guide for obtaining a certain result.

Analyzing various approaches to interpreting the concept of a module, Doctor of Pedagogical Sciences, Professor K. Ya. Vazina (1991) proposes to consider the module within methodological methods of displaying the external world in its inner essence. She believes that the "module" is an individualized concrete technology of personal development of both a teacher and a university student in the field of linguistics.

\section{PROPOSED METHODOLOGY}

Unlike dialogic speech, the MS structure consists of an introduction, a main part and a conclusion. 
The introduction plays a big role in establishing contact with the audience. The speaker's task is to present the topic / problem of the monologic statement as clearly as possible, to interest and induce listeners to communication and feedback.

The main part contains an argumentative description of authentic facts and events, reveals the ways and means of solving problems and appeals to listeners in the question format, motivating them to actively participate in monologic communication.

The conclusion consists of substantiated findings and reflects the speaker's personal attitude to the situation or the problem considered in the monologue. The essence of the topic is revealed through logically flawless and reliable arguments.

All parts of the monologue are interconnected, and each is continued in the next part. To achieve feedback and mutual understanding with listeners, a person should give them a speech that is motivating, emotional, situationally conditioned and structurally consistent. Only in this case it is possible to have a verbal impact on the audience. In this context the speech influence is regarded as a situation of verbal interaction when both the speaker and the listeners are equal participants of verbal communication.

The speech impact is enhanced if the monologue is accompanied by illustrative and graphic, multimedia or electronic presentation of the data. The audience manifests not only external activity, which results in the feedback, but also internal one, which is manifested at the consciousness level. Within this stage the listener comprehends the information experiencing a "dialogue" of his/her own thoughts and ideas with those received from the speaker. According to psychologists A. N. Leontiev (1981), A. A. Leontiev (2000) and I. A. Zimnyaya (1978), there is a complex process of listeners' intellectual work based on the dialogization of thinking, which reflects a full-fledged cognition act regardless of its practical and theoretical vector.

Psychologists classify dialogization means into internal and external ones. The techniques of the first type, which provide for an equal relationship between the addressee and the speaker, contribute to prompt contact establishment. The means of external dialogization, associated with attracting the addressee's attention, allow the speaker to "guide" the speech perception process and direct the interpretation of speech in conformity with the initial goals. The impact on the listener by using external dialogic forms is more effective, successful and reasonable within public communication.

The means of external dialogization of the speech impact on the audience include authorization techniques, "we" forms, appeals, question-and-answer unities, introductory constructions and the imperative mood. The internal dialogization can be defined as "emotional signals" that are not crucial for the content and structure of the speech, but can effectively attract the target audience's attention with their vivid speech form, appealing to the emotional and aesthetic sphere of consciousness. The means of internal dialogization conventionally include such elements as figurative means (metaphor), rhetorical questions and exclamations, repetitions (epiphora, anaphora) and the means of modality.

Methodical science devotes much attention to MS communicative functions. We support the position of V.L. Skalkin (1979) who considered the main communication areas and identified the range of MS communicative functions that ensure the process of verbal interaction within intercultural communication.

The informative function is aimed at 1) conveying new or significant information in the form of knowledge about objects and phenomena; 2 ) describing events, actions or states (for example, a public lecture, a report at a scientific and practical conference, a speech at a seminar, a roundtable discussion, a production report)

The influential function is associated with persuading the listener in something, for example, in the consistency or inconsistency of certain provisions of a concept, an activity programme, a newly adopted document, etc. 
The expressive (or emotional and expressive) function may be regarded as a regulator for relieving emotional stress and describing the speaker's psychological condition.

The entertainment function is a monologue of a person who is on stage or at a festive evening among his/her friends. It is possible to give other examples of using language for entertainment purposes: retelling and presenting stories, group language games (stories with errors "how, where, when", telecommunication games, etc.).

The ritual or ritual-cult function is manifested within a monologue presented at a wedding, anniversary, holiday party or another festive event.

\section{RESULT ANALYSIS}

Studying the use of MS modular teaching method within foreign-language education of language universities, we had to resort to scientific sources covering the history of the method's creation and its integration into foreign- language education. It was discovered that scientists' attention to this approach in the conditions of forming the intercultural paradigm of foreignlanguage education made it possible to identify the predominant characteristics of modular teaching. It was proved methodologically and didactically prospective considering the global (strategic) goal of teaching a foreign language - the development of a future linguist's cultural and linguistic personality.

Let us summarize the structure of the methodological model of MS modular teaching. 
Figure 1.2.1. The Structure of the Methodic Model for MS Modular Training

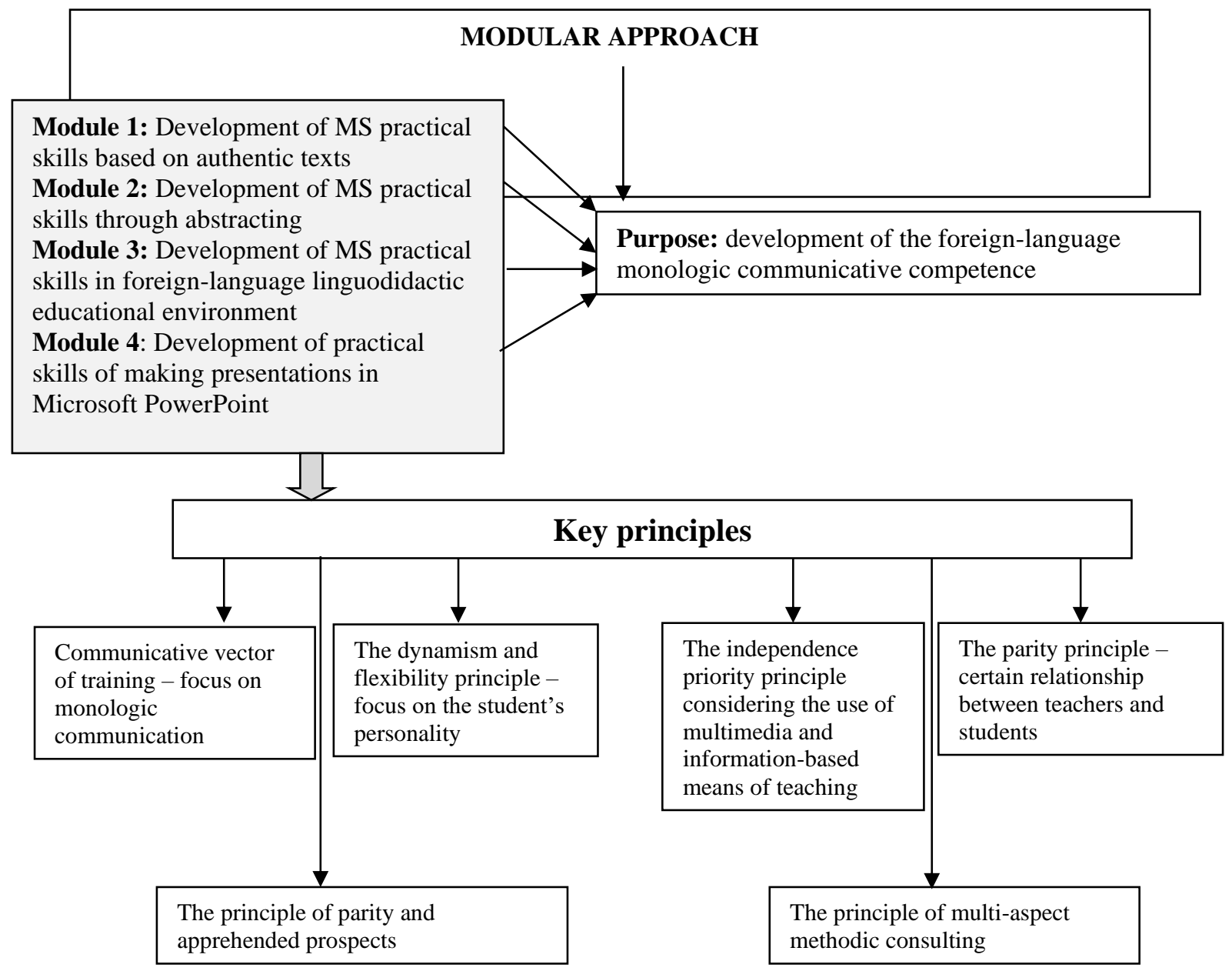

Speech activity on teaching prepared MS

Speech activity on teaching spontaneous MS

Independent creative speech activity

Using the scheme provides for the intelligible presentation of the system's elements that distinguish MS modular training from the traditional approach to this process.

MS modular training is a module-based didactic system as a unity of students' teaching and independent creative speech activity aimed at mastering the skills of monologic communication. Such system is built on the continuity of teaching MS and creates real conditions for the consistent development of students' practical skills which are the main components of the foreign-language monologic communicative competence.

The process of MS modular training is based on the key principles that determine its methodology:

the communicative orientation principle ensures monologic communication;

the dynamism and flexibility principle orients the learning process towards the student's personality, allows making timely changes in accordance with students' age and psychological characteristics, correcting the educational trajectories and considering students' interests within speech skills acquisition and development;

the principle of creativity and independence in mastering the module's content through information and multimedia technologies (preparing a presentation, an essay, a report, etc.) 
contributes to the development of creative thinking, the ability to predict, anticipate, design, plan and self-reflect;

the parity principle presupposes cooperation between the teacher and the student, within which the latter takes an active position, and the former supports him/her in solving the task;

the principle of conscious prospects and parity is aimed at students' awareness of the need to master MS for future professional activity, at forming the ability to think strategically and be ready for international professional communication;

the principle of multi-aspect methodological consulting presupposes the teacher's timely advice and recommendations to his/her students on completing their assignments or organizing independent work.

Creating the educational programmes based on the modular training principles ensures the continuity of MS skills development, the general coherence and transparency of the training content and consistent advancement from a lower to a higher level of the monologic competence. The student's progress in mastering MS manifests itself in his/her ability to participate in real communication activities and use communication strategies.

As indicated in the Common European Framework of Reference for Languages (Obshcheyevropeyskie ..., 2003), a strategy is a tool that a language user applies for mobilizing and balancing his/her resources to cope with a specific communication situation and solve a certain communication task in the most effective way according to the initial purpose. Therefore, communication strategies are the basis for determining the level of proficiency in dialogic and monologic speech.

Let us turn to the level scale designed for speaking. Describing the MS proficiency levels reveals its relationship with dialogical speech, which, in our opinion, should be considered when developing modular programmes for teaching a foreign language to junior students of linguistic specialities.

Table 1. Level scale designed for speaking

\begin{tabular}{|l|l|}
\hline C1 & $\begin{array}{l}\text { Extended monologue: description } \\
\text { ability to provide a clear and detailed statement on a complex issue; } \\
\text { ability to talk about something in detail, delving into sub-topics, developing certain } \\
\text { provisions and summarizing them with a suitable conclusion. }\end{array}$ \\
\hline B2 & $\begin{array}{l}\text { Ability to provide clear descriptions on multiple issues that are interesting to the } \\
\text { speaker: }\end{array}$ \\
\hline B1 & $\begin{array}{l}\text { ability to present familiar topics in simple language; } \\
\text { ability to describe something rather fluently, in simple language, or to talk about } \\
\text { something using a series of sequential statements; } \\
\text { ability to give someone detailed information about your experience, your reaction to } \\
\text { this experience, your feelings about it; } \\
\text { ability to talk in detail about something unexpected (an accident, for example); } \\
\text { ability to retell the plot of a book or a film and express your opinion; } \\
\text { ability to speak about your dreams, hopes, aspirations; } \\
\text { ability to speak about real and fictitious events; } \\
\text { ability to tell a story. }\end{array}$ \\
\hline B2 & $\begin{array}{l}\text { Extended monologue: giving arguments (for example, during the debates) } \\
\text { ability to develop a system of arguments, properly highlighting important points and } \\
\text { ability to develop a clear argumentation system, supporting your point of view with } \\
\text { sufficiently detailed statements and examples; } \\
\text { ability to present a number of substantiated arguments; }\end{array}$ \\
\hline
\end{tabular}




\begin{tabular}{|l|l|}
\hline & $\begin{array}{l}\text { ability to clarify your position on a topical issue, indicating the advantages and } \\
\text { disadvantages of various options. }\end{array}$ \\
\hline B1 & $\begin{array}{l}\text { ability to build argumentation in such a way that your thought is not difficult to follow; } \\
\text { ability to explain the reasons of something in a few words and comment on various } \\
\text { solutions, plans and actions. } \\
\text { Public reports: }\end{array}$ \\
\hline C1 & $\begin{array}{l}\text { ability to communicate fluently and without effort, using stress and intonation to } \\
\text { convey subtle semantic nuances in a more accurate way. }\end{array}$ \\
\hline B2 & $\begin{array}{l}\text { ability to present clear and fluent messages on the most general issues with little or } \\
\text { no preparation, without causing inconvenience to the listeners. }\end{array}$ \\
\hline B1 & $\begin{array}{l}\text { ability to make short, rehearsed announcements on a topic within your field of } \\
\text { activity, which are quite understandable despite the accent in stress and intonation. }\end{array}$ \\
\hline C1 & $\begin{array}{l}\text { Public speeches: } \\
\text { ability to make clear, well-structured reports on a complex topic, developing some } \\
\text { statements and supporting your point of view with additional reasoning, arguments } \\
\text { and suitable examples; } \\
\text { ability to "repulse" interruptions by responding immediately and effortlessly. }\end{array}$ \\
\hline B2 & $\begin{array}{l}\text { ability to make a clear, logically structured report, highlighting important points and } \\
\text { giving details that support your opinion; } \\
\text { ability to digress from the prepared text and develop interesting points of view } \\
\text { expressed by someone from the audience while demonstrating fluent speech and } \\
\text { formulating thoughts with ease. }\end{array}$ \\
\hline B1 & $\begin{array}{l}\text { ability to make a simple, pre-prepared report on a familiar topic within the scope of } \\
\text { your field of activity - a speech which will be clear to listeners throughout all its length, } \\
\text { both in general and in its main positions; } \\
\text { ability to answer a number of questions about your speech, sometimes repeating the } \\
\text { question if it was pronounced too fast. }\end{array}$ \\
\hline
\end{tabular}

\section{CONCLUSION}

MS modular teaching creates the prerequisites for the systematic mastering of speech and language skills by students with different monologic competence levels. Such organization of MS training stimulates future specialists to active speech activity.

The considerable research interest in the problem of modular learning is not accidental and is associated with objective circumstances. First, it should be noted that the need to organize and implement the learning process in the form of modules arose within the negatively evolving socioeconomic situation in different countries after the Second World War, which led to the destruction of the education sector. It was necessary not only to restore the structural and content forms of the educational process, but also to develop, create and introduce new forms of teaching, based on accelerating the training of specialists for all spheres of society by intensifying the individualization and systematization of the whole education. This new form was "modular training".

Secondly, as a response to the challenges of the post-war reality, B.F. Skinner (Skinner, 1968) proposed the development of modular training to the world pedagogical community, which was further developed by K. Kurch (1995) and all foreign scientists whom we mentioned when considering the concept of "module": V. Goldshmid, M. Goldshmid, D. Russell, G. Owens, etc.

Thirdly, the mass integration of "modular training" technologies into the western education was due to scientific-practical and methodological UNESCO conference, which was held in Paris in 1974. The following recommendations were developed: 
1) to design and create complexes of "open and flexible educational structures" which contribute to prompt adaptation to socio-economic and political transformations;

2) to introduce these developments in the field of science, considering their specific features, etc.

Authors' Contributions: Margarita Victorovna Myltseva: designed the study, prepared the plan, wrote the first draft of the manuscript and edited the final version. Ekaterina Alexandrovna Drozdova: designed the study, prepared the plan, wrote the first draft of the manuscript and edited the final version. Marina Georgiyevna Sergeeva: designed the study, prepared the plan, wrote the first draft of the manuscript and edited the final version. Dmitry Vladimirovich Lukashenko: designed the study, prepared the plan, wrote the first draft of the manuscript and edited the final version. All authors have read and approved the final version of the manuscript.

Ethics Approval: Not applicable.

Acknowledgments: Not applicable.

\section{REFERENCES}

Belyayev, B. V. (1965). Ocherki po psikhologii obucheniya inostrannym yazykam [Essays on the psychology of teaching foreign languages.]. Moscow: Prosveshcheniye.

Bírová, J., Kružlík, P., Kalimullin, A., Sokolova, N., Haroun, Z., Králik, R., Vasbieva, D. (2018). Mathematical and statistical bibliometric indicators for scholars in the field of Romance languages and Linguistics. EURASIA: Journal of Mathematics, Science and Technology Education, 14(12).

Blinova, S., Dugina, T., Zabolotskikh, A. (2018). Teaching mixed nationality groups (on the example of students from the Northern Caucasus region). INTED2018: Proceedings of the 12th International Technology, Education and Development Conference (pp. 7977-7982). Valencia, Spain.

Camargo, E. D. F., \& Givigi, R. C. N. (2021). The relationship between the school organization and the process of inclusion of an autistic student. Journal of Research and Knowledge Spreading, 2(1), e12354.

Dolzhich, E., Dmitrichenkova, S. (2018). Computer science terminology (a case study of the Spanish language). INTED2018: Proceedings of the 12th International Technology, Education and Development Conference (pp. 25562559). Valencia, Spain.

Garayev, V. M., Kulikov, S. I., Durko, Ye. M. (1987). Printsipy modul'nogo obucheniya [Principles of modular teaching]. Vestnik vysshey shkoly [Bulletin of Higher School], 2, 132-135.

Gorev, P., Telegina, N., Karavanova, L., Feshina, S. (2018). Puzzles as a didactic tool for development of mathematical abilities of junior schoolchildren in basic and additional mathematical education. EURASIA: Journal of Mathematics, Science and Technology Education, 14(10), 178-185.

Kovalyova, Yu. Yu. (2011). Modul'noye obucheniye inostrannomu yazyku studentov tekhnicheskogo vuza [Modular foreign language teaching for students of a technical university]. Vestnik Tomskogo gosudarstvennogo universiteta [Bulletin of Tomsk State University], 352, 180-182.

Kuimova, M. V. (2005). Obucheniye ustnoy monologicheskoy rechi s oporoy na autentichnyy pis'mennyy tekst. Angliyskiy yazyk, neyazykovoy vuz. [Teaching oral monologic speech based on an authentic written text. English, nonlinguistic university]: PhD thesis (pedagogy). Yaroslavl: Yaroslavl State Pedagogical University named after K.D. Ushinsky.

Kurch K. (1995). Modular Courses in British Higher Education. A critical assesment in Higher Education Bulletin, 3, 121123

Lapidus, B. A. (1986). Problemy soderzhaniya obucheniya yazyku v yazykovom vuze [Problems of the content of language teaching in a language university]. Moscow: Vysshaya shkola.

Leontyev, A. A. (2000). Yazyk i rechevaya deyatel'nost' v obshchey i pedagogichesko psikhologii: Izbrannyye psikhologicheskiye Trudy [Language and speech activity in general and educational psychology: Selected psychological works]. Moscow: Moscow Psychological and Social Institute.

Leontyev, A. N. (1981). Problemy razvitiya psikhiki [Issues of psyche development]. Moscow: Moscow State University. 
Mirolyubov, A. A. (2001). Kul'turovedcheskaya napravlennost' v obuchenii inostrannym yazykam. Istoriya otechestvennoy metodiki obucheniya inostrannym yazykam [Cultural orientation in teaching foreign languages. History of domestic methods of teaching foreign languages]. IYASH [Foreign Languages in School], 5, 11-15.

Obshcheyevropeyskiye kompetentsii vladeniya inostrannym yazykom: Izucheniye, prepodavaniye, otsenka [General European competences of a foreign language: studying, teaching, assessment] (2003). Cambridge: Cambridge University Press.

Rakhmanov, I. V. (1966). Nekotoryye voprosy obucheniya ustnoy rechi v yazykovom vuze [Some issues of teaching oral speech in a language university]. IYASH [Foreign Languages in School], 3, 13.

Rogova, G. V., Rozhkova F. M. (2012). Obucheniye svyaznomu vyskazyvaniyu [Teaching a coherent statement]. IYASH. Zolotyye stranitsy [Foreign Languages in School. Golden Pages], 6, 31-40.

Sharonova, S., Trubnikova, N., Sokolova, N. (2018). Interpreting religious symbols as basic component of social value formation. European Journal of Science and Theology, 14(3), 117-129.

Skalkin, V. L. (1979). Tipichnaya kommunikativnaya situatsiya kak strukturno-tematicheskaya osnova obucheniya ustnoy inoyazychnoy rechi [A typical communicative situation as the structural and thematic basis of teaching oral foreign-language speech]. Russkiy yazyk za rubezhom [The Russian Language Abroad], 5, 56-62.

Skinner, B. F. (1968). The Technology of Teaching. New York: Centery Grofts.

Sysoyev, P.V., Yevstigneyev, M.N. (2010). Metodika obucheniya inostrannomu yazyku s ispol'zovaniyem novykh informatsionno-kommunikatsionnykh tekhnologiy [Methodics of teaching a foreign language using new information and communication technologies]: A teaching and methodic guide for teachers, postgraduates and graduates. Rostovon-Don: Feniks.

Vasbieva, D. G., Sokolova, N. L., Masalimova, A. R., Shinkaruk, V. M., Kiva-Khamzina, Y. L. (2018). Exploring the EFL Teacher's Role in a Smart Learning Environment - A Review Study. XLinguae, 11(2), 265-274.

Vazina, K. Ya. (1991). Samorazvitiye cheloveka i modul'noye obucheniye [The human's self-development and modular teaching]. Nizhny Novgorod: VIPI.

Volkova, Y., Panchenko, N. (2018). Discourse variation of the concepts of destructive emotions. Vestnik Rossiiskogo Universiteta Druzhby Narodov. Russian Journal of Linguistics, 22(1), 175-194.

Yutsyavichene, P.A. (1989). Teoreticheskiye osnovy modul'nogo obucheniya [Theoretical foundations of modular teaching]: Grand PhD thesis (pedagogy). Vilnius.

Zimnyaya, H. A. (1978). Psikhologicheskiye aspekty obucheniya govoreniyu na inostrannom yazyke [Psychological aspects of teaching to speak a foreign language]. Moscow: Prosveshcheniye.

Received: 11 May 2021 | Accepted: 12 July 2021 | Published: 22 July 2021

This is an Open Access article distributed under the terms of the Creative Commons Attribution License, which permits unrestricted use, distribution, and reproduction in any medium, provided the original work is properly cited. 